\title{
Työn tehokkuuden määrittäminen ja vertailtavuus loppukasvattamoissa - Case-tutkimus kahdessa loppukasvattamossa
}

\author{
Tanskanen, Saana ${ }^{1}$, Viitala, Hannu ${ }^{1}$, Katriina Pylkkänen ${ }^{1}$, Palva, Reetta ${ }^{2}$, Wahlroos, Heli ${ }^{1}$ \\ 1) Savonia-ammattikorkeakoulu, PL 72, 74101 Iisalmi, etunimi.sukunimi@savonia.f \\ 2) TTS-Työtehoseura, etunimi.sukunimi@tts.fi
}

Naudanlihantuotannon kannattavuutta voidaan parantaa tehostamalla tuotantoa. Parantamalla työn tuottavuutta voidaan samalla työmäärällä hoitaa suurempi eläinmäärä. Lihantuotannossa ei kuitenkaan ole yleisesti käytössä työn tehokkuutta kuvaavaa yksikköä. Tutkimuksessa lanseerattiin uusi lihantuotantoon suunniteltu tehokkuusyksikkö tuotetut lihakilot per tehty kotieläintyön työtunti $\left(\mathrm{kg} \mathrm{h}^{-1}\right)$. Työssä selvitettiin, miten hyvin edellä mainittu yksikkö kuvaa case-tilojen tehokkuutta. Tiedonkeruumenetelminä käytettiin teemahaastatteluita ja videokuvaamista. Haastattelut tehtiin puhelimitse neljälle eri tilalle etukäteen laadittua kysymyspohjaa apuna käyttäen syys-lokakuussa 2016. Haastattelujen perusteella neljästä yhteistyötilasta valittiin kaksi case-tiloiksi. Varsinaiset työaikamittaukset case-tiloilla tehtiin videokuvaamalla päivittäiset eläintenhoitotyöt videokameran ja GoPro-kameran avulla lokakuussa 2016 ja tammikuussa 2017. Videoidut työvaiheet listattiin Excel-taulukkoon, jolloin saatiin selville päivittäisiin työvaiheisiin kulunut työaika. Harvemmin toistuviin eläintenhoitotöihin kulunut työaika selvitettiin teemahaastatteluiden avulla. Molemmilla tiloilla eniten työaikaa kului päivittäisiin rutiinitöihin. Eniten työaikaa kului ruokintaan eli tässä tapauksessa seosrehun valmistamiseen, jakamiseen sekä siirtymiin ruokinnan aikana. Ruokinta vei tilalla A 45\% ja tilalla B 41\% kaikista kotieläintyön työtunneista. Harvemmin toistuvista töistä eniten vuosityöaikaa kului molemmilla tiloilla karsinoiden pesuun ja desinfiointiin. Tehokkuus oli parempi tilalla A kuin tilalla B vaikka tilalla A on pidempi kasvatusaika (20,8 kuukautta) kuin tilalla B (18 kuukautta). Tulokseen vaikuttivat teuraspaino, tilan koko, eläinmäärä ja tehdyn työn suunnitelmallisuus ja yksinkertaisuus. Yhtä kotieläintyön työtuntia kohden tuotettiin lihaa tilalla A $82,3 \mathrm{~kg}$ ja tilalla B 57,7 kg. Molemmilla tiloilla työn tuottavuus on erittäin hyvä vertailuaineistoon verrattuna, jossa vaihteluväli on $3-80 \mathrm{~kg} \mathrm{~h}^{-1}$. Tehokkuuserot loppukasvattamoissa ovat suuria. Työt on kuitenkin mahdollista tehdä tehokkaasti ilman, että tuotannon laatu heikkenee. Työn tehokkuutta pystytään parantamaan kiinnittämällä huomiota työvaiheiden järkevyyteen ja yksinkertaisuuteen. Tämän työn jatkotutkimuksena voidaan tutkia muiden lihantuotannon tuotantosuuntien tehokkuutta ja tässä työssä lanseeratun tehokkuusyksikön käyttömahdollisuutta. Lisäksi voitaisiin vertailla taloudellisen kannattavuuden ja työn tehokkuuden välistä suhdetta lihantuotannossa. Jatkotutkimuksen aihe voisi olla myös tehokkuusyksikön kehittäminen myös muihin tuotantosuuntiin, esimerkiksi kasvintuotantoon, jossa yksikkö voisi olla tuotetut viljakilot/tehty työtunti.

Asiasanat: työn tehokkuus, tuottavuus, työaika 


\section{Johdanto}

Viime vuosina maatilat ovat pyrkineet parantamaan kannattavuutta esimerkiksi erikoistumalla tai tehostamalla tuotantoa, jolloin tilan kilpailukyky paranee. Erikoistuminen voi tarkoittaa esimerkiksi lihatuotteiden suoramyyntiä. Tuotantoa pystytään tehostamaan muun muassa kasvattamalla tilakokoa, lyhentämällä kasvatusaikaa tai kasvattamalla teuraspainoa (Kässi 2010). Yksi tapa parantaa tilan kannattavuutta on kiinnittää huomiota työn tehokkuuteen.

Työn tehokkuudesta puhuttaessa voidaan puhua myös työn tuottavuudesta. Talouskasvua ja kannattavuutta voidaan lisätä ja parantaa esimerkiksi työn määrää lisäämällä tai kasvattamalla työn tuottavuutta. Maatilalla tämä voisi tarkoittaa työn tuottavuuden parantamista tuotannon määrää lisäämällä edellyttäen, että työmäärä ei lisäänny samassa suhteessa. Toinen vaihtoehto on parantaa nykyisen tuotannon tuottavuutta tehostamalla työtä eli vähentämällä työmäärää. Tällä on vaikutusta talouteen erityisesti tiloilla, jotka käyttävät ulkopuolista palkkatyövoimaa. Yritykset yleensä pyrkivät tehokkaaseen tuotantoon taloudellisen tuloksen ja kannattavuuden parantamiseksi. Tuottavuutta voidaan parantaa esimerkiksi tehokkaammilla toimintatavoilla ja suorituskykyisempien koneiden avulla. (Elinkeinoelämän keskusliitto 2016). Maidontuotannossa työn tuottavuuden mittaamiseen käytetään yksiköitä tuotetut maitolitrat per tehty kotieläintyön työtunti (l/h) ja käytetyt työtunnit per lypsylehmä per vuosi (h/a) (Karttunen 2016).

Tutkimuksen aiheena oli työn tehokkuuden määrittäminen ja vertailtavuus suomalaisissa loppukasvattamoissa. Työn tarkoituksena oli tutkia, kuinka tehokasta tuotanto on kahdella tutkimuksessa mukana olleella case-tilalla. Tarkoituksena oli selvittää, mihin näillä tiloilla työaikaa kului ja mitkä työvaiheet veivät eniten työaikaa. Tehokkuuden määrittämiseksi työssä lanseerattiin lihantuotantoon suunniteltu tehokkuusyksikkö tuotetut lihakilot per tehty kotieläintyön työtunti $\left(\mathrm{kg} \mathrm{h}^{-1}\right)$. Tarkoitus oli selvittää, soveltuuko edellä mainittu tehokkuusyksikkö todella kuvaamaan näiden tilojen ja mahdollisesti myös yleisesti naudanlihatuotantotilojen tehokkuutta. Tehokkuusyksikön lanseeraamisessa hyödynnettiin kahta tutkimuksessa mukana ollutta case-tilaa. Tavoitteena kuitenkin oli, että yksikköä voitaisiin käyttää myös muussa lihantuotannossa.

\section{Aineisto ja menetelmät}

Tutkimuksessa oli mukana kaikkiaan neljä eri naudanlihantuotantotilaa, joilla on nautojen loppukasvatusta. Kaikki yhteistyötilat ovat olleet mukana Luonnonvarakeskuksen NautaNurmi-hankkeessa, jossa ne ovat tehneet muun muassa tuotantokustannuslaskelmia omilta tiloiltaan. Näissä laskelmissa tilat ovat jo valmiiksi pohtineet tilan työaikoja, mikä helpotti myös tämän tutkimuksen tekemistä.

Yhteistyötilat olivat kooltaan 170-550 loppukasvatuspaikkaisia. Osalla tiloista on loppukasvatuksessa olevien sonnien lisäksi myös lihahiehoja, emolehmiä ja lampaita. Viljelyksessä olevien peltohehtaarien määrä näillä tiloilla oli 100-500 hehtaaria. Tiloilla työskenteli 1-5 henkilöä vakituisesti ympärivuoden, joista osa työskenteli tilan muissa töissä, esimerkiksi koneurakointitöissä. Kaikista neljästä tilasta on kerrottu perustiedot taulukossa 1.

Työaikamittauksissa otettiin huomioon pelkästään loppukasvattamon eläintenhoitotyöt, koska niistä kertyi eniten työtunteja vuositasolla mitattuna. Kasvinviljelytyöt jätettiin mittauksista pois, koska tiloilla oli monia eri tapoja tehdä niitä (urakoitsijan käyttö yms). Kun otettiin huomioon pelkästään eläintenhoitotyöt, tilat saatiin vertailukelpoisiksi keskenään. Case-tiloiksi valikoitui kaksi naudanlihantuotantotilaa, jossa päivittäiset työvaiheet loppukasvatuksessa olevien maitorotuisten sonnien osalta olivat suunnilleen samanlaiset. Lisäksi toinen case-tiloista kuului kannattavuuskirjanpitoon, joten kotieläintyötunteihin menevää työaikaa oli kirjattu ylös useamman vuoden ajalta. Case-tilojen tutkimustuloksissa huomioitiin vain lämpimissä loppukasvattamoissa olevien maitorotuisten sonnien hoitoon kulunut työaika. Näin tutkimustilat saatiin keskenään vertailukelpoisiksi. Lisäksi tutkimusaineisto oli sopivan verran.

Tässä tutkimuksessa valittiin kaksi erikokoista loppukasvattamoa case-tapauksiksi, joiden pohjalta tietoa eläintenhoitotöistä ja siihen kuluvasta ajasta kerättiin. Ennen case-tilojen valintaa tehtiin teemahaastattelut neljälle eri tilalle, joista kaksi valittiin näiden perusteella case-tapauksiksi (tila A ja tila B). Teemahaastatteluissa teemana oli loppukasvattamojen eläintenhoitotyöt ja tarkoituksena selvittää kaikki vuosittaiset eläintenhoitotyöt loppukasvattamoissa. Varsinaiset työaikamittauksen päivittäisten 
eläintenhoitotöiden osalta tehtiin videoimalla. Harvemmin toistuvat eläintenhoitotyöt selvitettiin haastattelemalla viljelijöitä. Videoiden perusteella eriteltiin minuutin tarkkuudella päivittäiset eläintenhoitotyöt Excel-taulukkoon ennalta määrättyjen työvaiheiden alle, jotka olivat ruokinta, puhdistus, eläinten valvonta ja muut työt. Vastaavalla tavalla eriteltiin harvemmin toistuviin eläintenhoitotöihin kulunut työaika. Saatujen tulosten perusteella lanseerattiin uusi lihantuotannon tuottavuutta kuvaava yksikkö.

Taulukko 1. Tutkimuksen yhteistyötilat. Tiloilla A ja B suoritettiin teemahaastatteluiden lisäksi työaikamittaukset. Tiloilla C ja D tehtiin pelkästään teemahaastattelut.

\begin{tabular}{|c|c|c|c|c|}
\hline & Tila A & Tila B & Tila C & Tila D \\
\hline Eläimet & $\begin{array}{l}\text { maito/risteytys- } \\
\text { sonneja }\end{array}$ & $\begin{array}{c}\text { maito/risteytys/liha- } \\
\text { sonneja, } \\
\text { maito/risteytys/liha- } \\
\text { hiehoja, } \\
\text { emolehmiä }\end{array}$ & $\begin{array}{l}\text { maito/risteytys- } \\
\text { sonneja }\end{array}$ & $\begin{array}{l}\text { lihasonneja, } \\
\text { lihahiehoja, } \\
\text { emolehmiä, } \\
\text { lampaita }\end{array}$ \\
\hline Eläinmäärä/kpl* & 230 & $\begin{array}{l}\text { m/r-sonnit: } 250 \\
\text { lihasonnit: } 160 \\
\text { hiehot: } 140 \\
\text { emot: } 100\end{array}$ & $170-180$ & $\begin{array}{c}\text { lihasonneja: } 110 \\
\text { lihahiehoja: } 150 \\
\text { emolehmiä: } 90 \\
\text { lampaita: } 100 \text { uuhta, } \\
\text { 150-200 karitsaa }\end{array}$ \\
\hline Peltoala/ha & 165 & 500 & 110 & 280 \\
\hline Kasvatusaika/kk* & 20,8 & $\begin{array}{c}\text { sonnit: } 18 \\
\text { lihahiehot: } 14 \\
\text { m/r-hiehot: } 14-15 \\
\end{array}$ & $19-20$ & $\begin{array}{l}\text { lihasonnit: } 18-20 \\
\text { lihahiehot: } 14\end{array}$ \\
\hline Päiväkasvu/g* & n. 620 & $\begin{array}{c}\text { m/r-sonnit: } \text { n. } 550-570 \\
\text { lihasonnit: yli } 700 \\
\text { m/r-hiehot: yli } 350 \\
\text { lihahiehot: } \text { n. } 592\end{array}$ & n. 610 & $\begin{array}{l}\text { lihasonnit: n. } 800 \\
\text { lihahiehot: n. } 600\end{array}$ \\
\hline Teuraspaino/kg* & n. 379 & $\begin{array}{l}\text { m/r-sonnit: } \text { n. } 350 \\
\text { lihasonnit: n. } 450 \\
\text { m/r-hiehot: yli } 210 \\
\text { lihahiehot: } \text { n. } 269\end{array}$ & n. 360 & $\begin{array}{l}\text { lihasonnit: n. } 450 \\
\text { lihahiehot: } \text { n. } 270\end{array}$ \\
\hline
\end{tabular}

${ }^{*} \mathrm{~m} / \mathrm{r}=$ maito/risteytysrotuiset

\section{Tulokset}

Case-tilojen väliltä löytyi melko suuriakin eroja päivittäisissä työajoissa ja työvaiheissa, vaikka tarkastelun kohteena oli pelkästään vuosittaiset kotieläintenhoitotyöt. Päivittäisissä eläintenhoitotöissä perustyövaiheet olivat molemmilla case-tiloilla samat. Työmenetelmät olivat kuitenkin osittain erilaiset.

Tuotetut lihakilot/tehty kotieläintyön työtunti $\left(\mathrm{kg} \mathrm{h}^{-1}\right)$-yksikön avulla vertailtiin kahden Case-tilan työn tuottavuutta. Samalla testattiin, kuvaako uusi yksikkö todella tilan tuottavuutta. Tässä tutkimuksessa perehdyttiin ainoastaan yksikön käyttöön naudanlihantuotannossa ja nautojen loppukasvatuksessa. Yksikköä pystytään käyttämään tilan tuottavuuden kuvaamiseen, jos siinä huomioidaan kaikki tarvittavat seikat, myös muussa lihantuotannossa. 


\section{Työaikamittaukset}

Molemmilla tiloilla eniten työaikaa kului päivittäisiin rutiinitöihin, joista eniten työaikaa kului ruokintaan. Ruokinta vei vuosityöaikaa tilalla A 45 \% ja tilalla B 41 \% kaikista kotieläintyön työtunneista (Kuva1). Harvemmin toistuvista töistä eniten vuosityöaikaa molemmilla tiloilla vei karsinoiden pesu ja desinfiointi.

Tila A

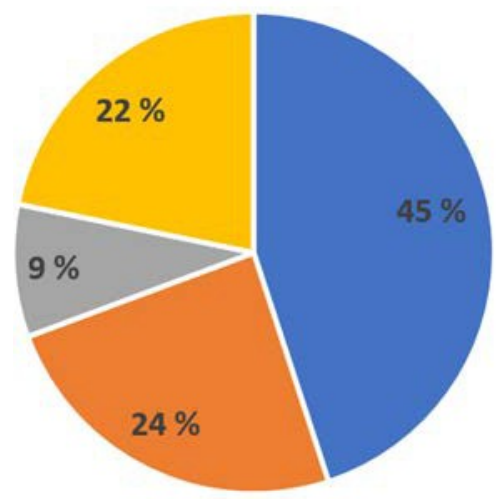

- Ruokinta

- Puhdistus

- Eläinterveys ja valvonta

Muut työt
Tila B

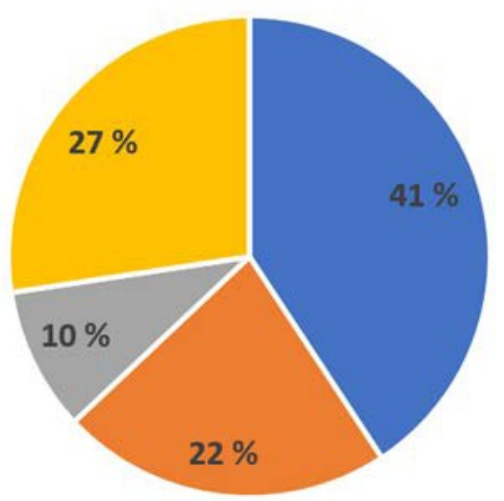

Kuva 1. Eniten vuosityöaikaa vievät työvaiheet tutkimustiloilla

Työn tuottavuus oli parempi tilalla A kuin tilalla B. Käytetyt kotieläintyön työtunnit yhtä eläintä kohden vuodessa tilalla A oli 2,7 tuntia ja tilalla B 4,0 tuntia. Yhtä kotieläintyön työtuntia kohden tuotettiin lihaa tilalla A 82,3 kg ja tilalla B 57,7 kg. Työn tuottavuus laskettiin uudella tuotetut lihakilot/tehty kotieläintyön työtunti $\left(\mathrm{kg} \mathrm{h}^{-1}\right)$-yksiköllä.

\section{Tuotetut lihakilot/tehty kotieläintyön työtunti (kg/h) -yksikön käyttö}

Alle on listattu huomionarvoiset seikat, joita yksikön käyttö vaatii, jotta tulokset olisivat todenmukaisia ja vertailukelpoisia keskenään. Yksikköä käytetään nimenomaan vertailtaessa tuotannon tehokkuutta työn tehokkuuden näkökulmasta. Se ei ota suoranaisesti kantaa esimerkiksi tilan kannattavuuteen tai siihen, miten järkeviä tai oikeita työtehtävään käytetyt työmenetelmät ovat.

1. Yksikköä käytettäessä huomioidaan vain kotieläintyön tunnit. Laskelmissa tulee huomioida kaikki kotieläinten hoitoon käytettävät työtunnit.

2. Kokonaistyöaika tulee laskea eläinryhmittäin. Esimerkiksi nautojen loppukasvatuksessa maitorotuiset sonnit, liharotuiset sonnit, maitorotuiset hiehot ja liharotuiset hiehot.

3. Kokonaistyöaika tulee määrittää tietylle ajanjaksolle, jotta myös harvemmin toistuvat työt tulee huomioitua.

4. Laskettuun kokonaistyöaikaan tulee lisätä tietty työtunti määrä tiettynä prosenttiosuutena kokonaistyöajasta (esimerkiksi naudan loppukasvatuksessa + 5\% kokonaisvuosityöaikaan).

5. Kokonaistyöaika tulee jakaa eläinten keskimääräiselle kasvatusajalle.

6. Yhtä eläintä kohden käytetty työaika (h/eläin) määritetään kasvatusaikana käytetyistä työtunneista.

7. Eläinkohtainen työaika kasvatusaikana tulee jakaa keskimääräisellä teuraspainolla.

8. Tilan jokaiselle eläinryhmälle lasketaan oma työn tehokkuutta kuvaava luku ja eri eläinryhmistä voidaan laskea keskiarvo, joka kuvaa koko tilan työn tehokkuutta.

Tätä yksikköä käytettäessä on huomioitava, yllä kuvailtavat ehdot on määriteltävä erikseen kullekin lihantuotannon tuotantosuunnalle. Lisäksi loppukasvatuksen osalta yksikkö huomioi eläimen koko 
kasvatusajan eli loppukasvattamon kuukausittainen eläintenhoitotyöhön kulunut aika kerrotaan kasvatuskuukausilla. Alku- ja välikasvatus ei kuitenkaan yleensä tapahdu samalla tilalla, mutta loppukasvatus kestää kasvatusvaiheista pisimään. Kun keskimääräinen teuraspaino ja kasvatusaika huomioidaan, saadaan eri loppukasvattamot vertailukelpoiseksi yksikön käytön suhteen. Tulokset eivät kerro suoraan jokaista tilan työtuntia kohden tuotetun lihan määrää, mutta se vastaa hyvin kysymykseen, kuinka tehokasta työn käytöltään tilan toiminta on. Yksikkö huomioi myös tuotannon laadun, kun tuottavuuslukua laskettaessa käytetään keskimääräistä kasvatusaikaa ja keskimääräistä teuraspainoa.

\section{Johtopäätökset}

Työssä lanseerattu tuottavuus yksikkö kuvaa hyvin case-tilojen työn tehokkuutta. Kun yksikköä käytetään tutkimuksessa kuvatulla tavalla, se soveltuu hyvin kuvaamaan nautojen loppukasvatustilan tuotannon tehokkuutta. Yksikön käyttö on helppoa ja yksinkertaista ja herättää pohtimaan, miksi kahdella tilalla on erilaiset tuottavuutta kuvaavat luvut.

Molemmat tutkimuksessa mukana olleet case-tilat olivat työn käytöltään hyvin tehokkaita, mutta erot tilojen tuottavuudessa olivat melko suuria. Tällä perusteella voidaan myös yleisesti todeta, että loppukasvattamoiden tuottavuudessa on todennäköisesti isoja eroja, vaikka päivittäiset työvaiheet tiloilla ovatkin melko yksinkertaiset. Myös loppukasvattamossa työt voidaan tehdä tehokkaasti, joka parantaa työn tuottavuutta. Toisaalta tämä osoittaa myös sen, että heikoimpien tilojen työn tehokkuudessa on tällä perusteella paljonkin kehitettävää. Tutkimus osoitti, että erityisesti ruokinnalla ja sen tehokkuudella oli iso merkitys tilan tuottavuuden kannalta. Työn tehokkuus ei kuitenkaan heikennä tuotannon laatua. Case-tiloja vertailtaessa huomattiin, että tuotannon laatu (teuraspaino, kasvatusaika) oli molemmilla tiloilla lähes yhtä hyviä, vaikka tila A oli työn käytöltään tehokkaampi kuin tila B. Tämä osoittaa sen, että työt on mahdollista tehdä tehokkaasti ilman tuotannon laadun heikkenemistä. Tällä on todennäköisesti positiivisia vaikutuksia myös tilan taloudelliseen kannattavuuteen.

Työn tehokkuuteen tilalla vaikuttavat erityisesti töiden organisointi ja tuotantoympäristö. Monipuolinen tuotanto ja pitkät siirtymät heikentävät työn tehokuutta varsinkin yhtä eläinryhmää vertailtaessa. Isolla tilalla, jossa on monipuolista lihantuotantoa, myös työvaiheita on enemmän ja työhön kulunutta aikaa on vaikeampi arvioida.

Tutkimus osoitti, että hyviin työn tuottavuuden lukuihin pääseminen vaatii paljon pohdintaa ja työtä, mutta sillä on positiivisia vaikutuksia tilan tehokkuuteen ja todennäköisesti myös taloudelliseen kannattavuuteen. Päivittäiset työvaiheet tulee olla harkitut ja yksinkertaiset. Erityisesti tulee kiinnittää huomiota työmenetelmiin, jotta ylimääräiset ja aikaa vievät työvaiheet jäävät pois. Tuotannon laatu tulee olla hyvällä tasolla eli teuraspaino ja kasvatusaika tulee olla optimaalinen kasvatettavalle eläinryhmälle. Olennaisesti tehokkuuteen vaikuttaa myös eläinten määrä. Tuotantorakennusten sijainti ja rakennusratkaisut vaikuttavat päivittäiseen työn tehokkuuteen. Erityisesti ruokinnan tehokkuudella on iso vaikutus vuosityöaikaan. Jotta ruokinta olisi tehokasta, tulisi myös koneiden olla optimaalisen kokoisia tilalla ja kohtuullisen uusia, jotta rikkoutumisilta vältyttäisiin. Ratkaisevimmassa roolissa on kuitenkin kiinnostus omaan työhön ja ammattiosaaminen tilalla. Lihantuotannon tuottavuusyksikköä käytettäessä tärkeintä ei ole saatu tulos vaan se, miten tähän tulokseen on päästy ja kuinka sitä voidaan parantaa. Ratkaisevassa roolissa on se, mitä tila itse haluaa. Esimerkiksi toiselle voi olla tärkeämpää, että työtä tehostamalla saa lyhennettyä puolisen tuntia päivittäistä työaikaa. Toiselle voi merkitä enemmän se, että samalla työhön käytettävällä ajalla voi hoitaa isomman määrän eläimiä.

\section{Kirjallisuus}

Elinkeinoelämän keskusliitto 2016. Tuottavuus ja kilpailukyky [verkkosivu]. Elinkeinoelämän keskusliitto [viitattu 05.04.2016]. https://ek.fi/mita-teemme/talous/perustietoja-suomen-taloudesta/tuottavuus-ja-kilpailukyky/

Karttunen, J. 2016. Karjanhoitotyön tuottavuus automaattilypsytiloilla. Tutkimustiedote. TTS Työtehoseura. Kässi, P. 2010. Lihantuotannon kannattavuus haasteena [verkkosivu]. Nauta-lehti [viitattu 16.03.2016]. https://portal.mtt.fi/portal/page/portal/mtt/mtt/esittely/toimipaikat/ruukki/Tietopankki/Naudanlihantuotanto/52010\%20s40-41.pdf 